\title{
HETEROSTYLY AND HOMOSTYLY IN PRIMULA OBCONICA
}

\author{
V. PAMELA J. DOWRICK \\ John Innes Horticultural Institution, Bayfordbury, Hertford, Herts
}

\section{INTRODUCTION}

Received I.ix.55

THE complex of characters, both morphological and physiological, which distinguishes the two mating types of most distylic species of plants, is well known. The thrum plant has flowers with short styles, high anthers, large pollen and short stigmatic papillæ; while the pin has long styles, low anthers, small pollen and long papillæ. The two forms of pollen and style differ physiologically, so that pollinations within mating types are incompatible, but between two types are compatible.

The genetic control of distyly is also remarkably similar in most species. One gene complex controls the difference, thrum being a heterozygote, Ss and pin the recessive homozygote, ss. In autotetraploids of Primula sinensis the expression and segregation of the $\mathbf{S}$ complex is known to be quite regular. The simplex form, Ssss, is a thrum, thus showing the complete dominance of $\mathbf{S}$.

Abnormal plants which show combinations of some thrum and some pin characters have been found in many species. Certain of these abnormalities have the style and anthers at the same level, and are described as homostyles. In $P$. sinensis the homostyles are the result of mutant genes at loci other than that of the $\mathbf{S}$ complex (Mather, I950). However, in Primula viscosa and Primula hortensis (Ernst, 1936b), and in Primula vulgaris (Crosby, I949a), the homostyles are the result of a change in the $\mathbf{S}$ complex itself. It has not been proved whether this change is the result of a mutation of one or more of the $\mathbf{S}$ subgenes or of crossing-over within the $\mathbf{S}$ complex.

Primula obconica, the subject of this study, is a typical distylic species which exists in both diploid and autotetraploid forms. Homostyles have not been found in the diploids but are present in the tetraploids.

The main objects of this investigation were to study :

I. The morphological and physiological characters controlled by the $\mathrm{S}$ complex in diploid and tetraploid $P$. obconica.

2. The inheritance of the $\mathbf{S}$ complex in both forms and the genetics of the homostyle tetraploid.

3. The structure and behaviour of the S complex; the mode of its breakdown, and the relationship if any between breakdown of the $\mathbf{S}$ complex and polyploidy. 


\section{MATERIAL AND METHODS}

Diploid and autotetraploid horticultural varieties of $P$. obconica were used.

Pollen grains, stigmatic papillæ and conducting tissue were stained in Cotton Blue, hand sections being used for the last named tissue.

Compatibility was tested initially by pollen-tube growth in the style. Flowers were removed from the plants, pollinated, and kept in an incubator at $25^{\circ} \mathrm{C}$. for twenty-four hours. Styles were then removed from the flowers and fixed in $1: 3$ acetic alcohol for twenty-four hours and stained in acid fuchsin and light green (Darlington and La Cour, 1947). They were softened in water, halved longitudinally, and squashed before warming in stain for ten minutes.

Although normally grown under glass, large progenies of the tetraploid were raised by sowing under glass in January and planting outside at the end of May. A sufficient proportion flowered under outdoor conditions.

I am grateful to Messrs J. T. Jansen of Hertford and H. Owens of Bath for gifts of plants of $P$. obconica.

\section{CHARACTERS CONTROLLED BY THE S COMPLEX}

\section{(i) Morphological}

As in other Primula species, the diploid pins have long styles, low anthers, long stigmatic papillæ and small pollen grains, when compared with thrums. The tetraploid pin and thrum have similar

TABLE I

The morphology of distyly in diploid and tetraploid P. obconica

\begin{tabular}{|c|c|c|c|c|}
\hline \multirow{2}{*}{ Ploidy } & \multicolumn{4}{|c|}{ Thrum } \\
\hline & Style length & Anther height & $\begin{array}{c}\text { Stigmatic } \\
\text { papilla length }\end{array}$ & $\begin{array}{l}\text { Pollen grain } \\
\text { volume }\end{array}$ \\
\hline \multirow[t]{2}{*}{$\begin{array}{l}2 \\
4\end{array}$} & $\begin{array}{l}5^{\circ} \mathrm{o} \\
4^{\circ} 9\end{array}$ & $\begin{array}{l}8 \cdot 7 \\
9 \cdot 5\end{array}$ & $\begin{array}{r}8 \cdot 26 \\
12 \cdot 78\end{array}$ & $\begin{array}{l}3750 \\
7300\end{array}$ \\
\hline & \multicolumn{4}{|c|}{ Pin } \\
\hline \multirow[t]{2}{*}{$\begin{array}{l}2 \\
4\end{array}$} & $\begin{array}{r}9 \cdot 5 \\
11 \cdot 2\end{array}$ & $\begin{array}{l}4 \cdot 2 \\
4 \cdot 5\end{array}$ & $\begin{array}{l}28 \cdot 70 \\
45 \cdot 96\end{array}$ & $\begin{array}{l}165^{\circ} \\
3100\end{array}$ \\
\hline & \multicolumn{4}{|c|}{ long-styled homostyle } \\
\hline $\begin{array}{l}2 \\
4\end{array}$ & 10.8 & $\begin{array}{l}\ldots \\
9 \cdot 5\end{array}$ & $\begin{array}{c}\cdots \\
42 \cdot 5^{6}\end{array}$ & $\ddot{6400}$ \\
\hline
\end{tabular}

Style length and anther height are measured in mm. from the level of corolla abscission, stigmatic papilla length in $\mu$; and pollen grain volume in $\mu^{3}$.

differences as shown by the measurements given in table I. Measurements of the tetraploid homostyle showed that the style is of pin length and stamens are at the thrum level; pollen is large, i.e. of the thrum type and stigmatic papillæ are long like those of a pin stigma. 
A further difference between pin and thrum has been noted in both diploid and tetraploid $P$. obconica. The cross thrum $\times$ pin is more fertile than the reciprocal cross (table 2).

TABLE 2

The comparative fertility of reciprocal crosses in $\mathrm{P}$. obconica

\begin{tabular}{|c|c|c|}
\hline Ploidy & Pin $\times$ thrum & Thrum $\times$ pin \\
\hline 2 & 64.9 & ro6.r \\
4 & 69.4 & $89 \cdot 2$ \\
\hline
\end{tabular}

Fertility is measured by the mean seed-set per capsule.

It is interesting that Darwin (1862 and 1877) discovered the same relationship in other Primula species, and that $P$. sinensis data from other sources are in agreement (see table 3). In his "Forms of Flowers ", Darwin states that, " the short-styled plants produce more seed than the long-styled, in P. veris and other species of Primula".

TABLE 3

Comparison of the fertility of reciprocal compatible crosses in Primula

\begin{tabular}{|c|c|c|c|c|c|c|}
\hline & \multicolumn{2}{|c|}{$\begin{array}{l}\text { Hildebrand } \\
\left(\mathrm{r} 86_{4}\right)\end{array}$} & \multicolumn{2}{|c|}{$\begin{array}{c}\text { Darwin } \\
\text { (1862 and } 1877 \text { ) }\end{array}$} & \multicolumn{2}{|c|}{$\begin{array}{c}\text { Mather and } \\
\text { de Winton (r94r) }\end{array}$} \\
\hline Species & ss & Ss & ss & Ss & ss & Ss \\
\hline $\begin{array}{l}\text { P. auricula } \\
\text { (after Kerner) }\end{array}$ & & & 73 & $9^{8}$ & & \\
\hline P. elatior & & & $46 \cdot 5$ & $47 \cdot 7$ & & \\
\hline$P$. sinensis & $4^{r}$ & 44 & 50 & 64 & $17 \cdot 8$ & $30 \cdot 0$ \\
\hline$P$. veris & & & $\begin{array}{l}\text { (1) } 34 \\
\text { (2) } 62 \cdot 8\end{array}$ & $\begin{array}{l}4 I \\
44^{\prime} \cdot 5\end{array}$ & & \\
\hline P. vulgaris & & & $\begin{array}{l}\text { (1) } 20 \\
\text { (2) } 66 \cdot 9\end{array}$ & $\begin{array}{l}40 \\
65.0\end{array}$ & & \\
\hline
\end{tabular}

Fertility is measured by mean number of seeds per capsule and, for figures in italics, by the mean weight in grains per 100 capsules. These weights probably underestimate the difference in fertility since Darwin recorded that pin ovules of $P$. veris were larger than thrum. The second values for $P$. veris and $P$. vulgaris are the result of artificial pollinations. It must be assumed that these are not truly representative, since Darwin noted that seed production was greater in the thrum for these species.

Ernst, too, has noted such a difference. Thus it appears that differences in fertility (seed production), must be included as a feature of dimorphism in Primula species.

This difference in fertility was investigated further in $P$. obconica. Pin and thrum ovaries show no difference in the number of ovules 
they contain, which is about double the number of seeds set. Therefore, this cannot be a limiting factor in seed production. There must, then, be some other factor to account for a reduced seed set in pin forms. Measurements show that there is a much smaller area of conducting tissue available for pollen-tube growth in pin than in thrum styles (see table 4).

The larger size of thrum pollen does not result in significantly wider pollen tubes, but is presumably correlated with the extra growth in tube length. (If they are wider, then this factor would further reduce the amount of pollen able to grow down the pin styles.) Thus, once it is shown that pollen tube growth is restricted, then the diameter of the conducting strand must be the factor governing the difference in seed production.

There is, in fact, a physical limit to the number of tubes which can grow down a style, those which are "crowded out" giving rise to a secondary zone of short tubes, unable to continue growth. Modlibowska (1942), showed that in $P$. obconica, "particularly in the cross pin $\times$ thrum" there was bimodality of pollen-tube growth after

TABLE 4

Area of cross section of conducting tissue in the style measured in $\mu^{2}$

\begin{tabular}{|c|c|c|}
\hline Ploidy & Thrum & Pin \\
\hline 2 & 284.8 & $\mathrm{I} 27.5$ \\
4 & 305.5 & $\mathrm{I} 63.8$ \\
\hline
\end{tabular}

heavy pollination. This was not due to the two genotypically different forms of thrum pollen, $\mathbf{S}$ and $\mathbf{s}$, since it did not appear after restricted pollination. That bimodality was most striking in pin styles is to be expected as the available area is smaller.

Thus, another morphological difference exists between the two forms in $P$. obconica, and is, most probably, present in other Primula species. Whether this is to be regarded as distinct from the stylelength character, or as another effect of the same basic difference, is, at present, unknown.

\section{(ii) Physiological}

Incompatibility is the result of physiological differences in the styles and pollen of the two forms of plant. These are controlled by the $\mathrm{S}$ complex. In the diploid $P$. obconica, as with other heterostyled species, thrum $\times$ pin and pin $\times$ thrum are the compatible unions, there is a full seed set and the pollen tubes grow $3 \mathrm{~mm}$. in 24 hours. After self-pollination no seeds are produced and pollen tubes rarely penetrate the stigma in 24 hours. 
Incompatibility behaviour of the tetraploid thrum and pin was practically identical with the diploid. Self-pollination of pin plants did, however, sometimes give a number of long pollen tubes after 24 hours and set small quantities of seed. Thus in tetraploids the incompatibility reaction is not as rigorous as in diploids. Pollen-tube growth studies of the tetraploid long homostyle showed that the incompatibility reaction of the style was "pin" and the pollen behaved as "thrum" (see fig. I). Thus, homostyle $\times$ thrum and pin $\times$ homostyle were compatible crosses; the reciprocal crosses were incompatible, and the homostyle was self-fertile.

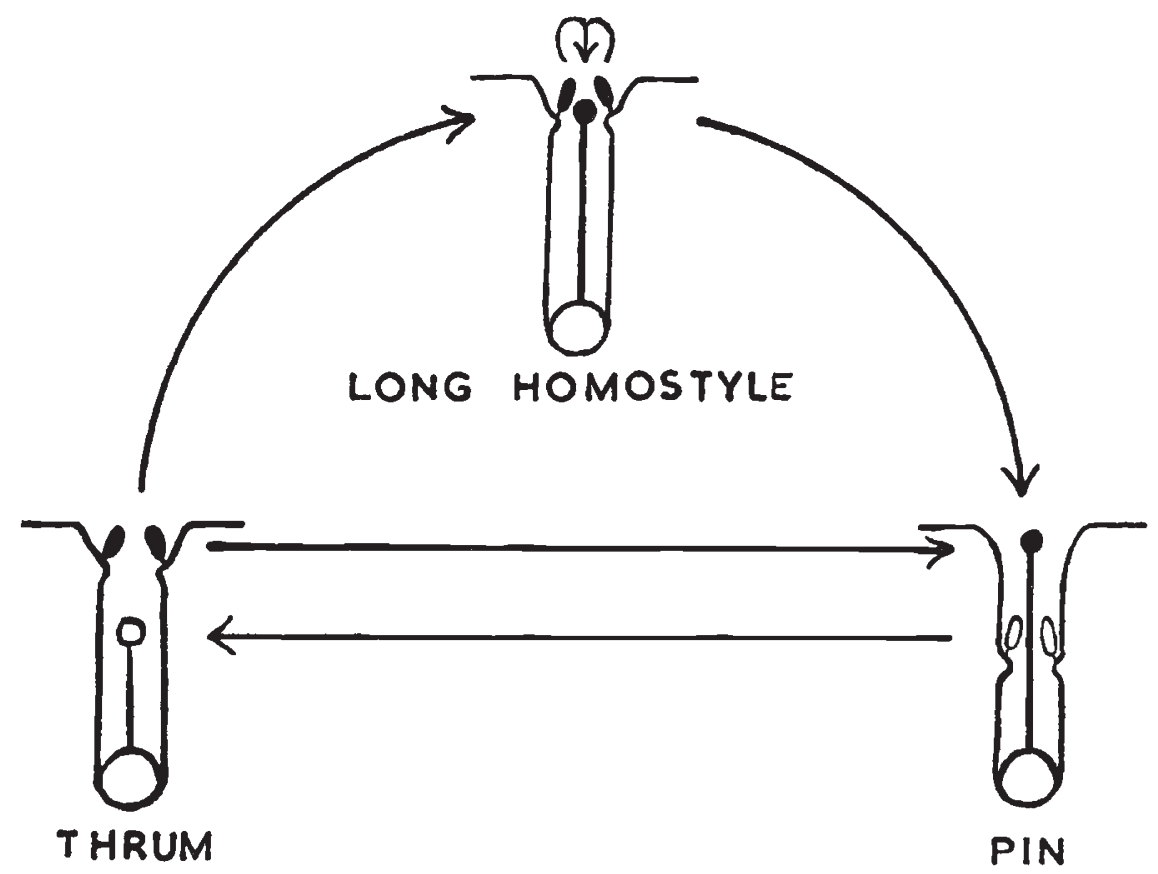

FIG. I.-Compatibility relationships of the three forms of tetraploid P. obconica. Similar shading and arrows indicate the compatible unions.

\section{THE INHERITANCE OF THE S COMPLEX}

In diploid $P$. obconica, as in other heterostyled species, the $\mathbf{S}$ gene complex is inherited as a single gene pair, S-s. Thrum is the dominant form and is heterozygous, Ss; pin is the homozygous recessive, ss. There is sporophytic control of the pollen so that both genotypes of thrum pollen have the same compatibility behaviour.

In the tetraploid form reciprocal crosses were made between thrum and pin plants. The progeny approximated to $\mathrm{I}: \mathrm{I}$ ratios of the two forms (see table 5). Therefore, the thrum plants must have been simplex for $\mathbf{S}$, and furthermore the $\mathbf{S}$ allele shows complete dominance, as in $P$. sinensis. 
It should be pointed out that, in a normal equilibrium population of tetraploid pins and thrums, all the thrums will be simplex. In whatever way the tetraploid thrum arose from the diploid, since it is strictly self-incompatible, it can only reproduce by crossing with the recessive pin. In this way forms containing more than one $\mathbf{S}$ allele would disappear and the simplex thrums remaining would maintain a population of equal numbers of simplex thrums and pins.

TABLE 5

Inheritance of the $\mathbf{S}$ complex in the tetraploid form

\begin{tabular}{|c|c|c|c|}
\hline & & Thrums & Pins \\
\hline $\begin{array}{l}\text { Thrum (1) } \times \text { pin } \\
\text { Thrum (2) } \times \text { pin } \\
\text { Thrum (3) } \times \text { pin }\end{array}$ & & $\begin{array}{l}36 \\
66 \\
90\end{array}$ & $\begin{array}{l}46 \\
71 \\
85\end{array}$ \\
\hline $\begin{array}{l}\text { Pin } \times \text { thrum (I) } \\
\text { Pin } \times \text { thrum (2) } \\
\text { Pin } \times \text { thrum (3) }\end{array}$ & & $\begin{array}{r}20 \\
\times 55 \\
61\end{array}$ & $\begin{array}{r}23 \\
157 \\
77\end{array}$ \\
\hline Total & & 428 & $45^{8}$ \\
\hline
\end{tabular}

The above results all agree with $1: 1$ ratios.

Crosses were also made to investigate the inheritance of homostyly (see table 6). The first cross shows that the homostyle does not carry the thrum allelomorph-S. The second, indicates that it is duplex, either for a distinct gene (HHhhssss, where $\mathbf{H}$ is epistatic over $\mathbf{s}$ but not over $\mathbf{S}$ ), or for an allele of the $\mathbf{S}$ complex $\left(\mathbf{S}^{1} \mathbf{S}^{1} \mathbf{s} \mathbf{S}, \mathbf{S}^{1}\right.$ being recessive to $\mathbf{S}$ but dominant over $\mathbf{S}$ ). The $5:$ I ratio in the first agrees with either hypothesis, as does the $35:$ I ratio from selfing.

TABLE 6

The inheritance of the tetraploid long homostyle form

\begin{tabular}{|c|c|c|c|c|}
\hline Parents $\quad \begin{array}{c}\text { Progeny } \\
\text { classes }\end{array}$ & Thrum & Homostyle & Pin & Ratio \\
\hline (I) Pin $\times$ homostyle & o & 57 & 12 & $0: 5: I$ \\
\hline (2) Homostyle $\times$ thrum . & 44 & 36 & II & $6: 5: I$ \\
\hline (3) Homostyle selfed & o & 99 & 5 & $0: 35: 1$ \\
\hline
\end{tabular}

Thus homostyly in this species could be either of the kind found in $P$. sinensis, or of that found in $P$. hortensis, $P$. viscosa and $P$. vulgaris. To distinguish between these two possibilities it was necessary to analyse thrum plants obtained from the cross, long homostyle $\times$ thrum 
(see table 7). Nineteen of these, taken at random, were back crossed and the progeny scored (see table 8 ).

The results, when taken together, fit the ratios expected on the $\mathbf{S}$ allele theory. Individual families, too, fit these ratios, with the exception of $24^{6}$ progeny, which fits the $2:$ I : I ratio slightly better, and that of $24^{2}$ which fits neither. Therefore, homostyly in tetraploid $P$. obconica is controlled by the S complex. Thus, this example is comparable with the majority of cases of homostyly in the genus, $P$. sinensis being the exception.

\section{TABLE 7}

The constitutions of thrum plants from the cross, long homostyle $\times$ thrum, and the ratios expected when these are backcrossed, for the two possible homostyle genotypes

\begin{tabular}{|c|c|c|c|c|c|c|}
\hline \multirow{2}{*}{ Theory } & \multirow{2}{*}{\multicolumn{3}{|c|}{$\begin{array}{l}\text { Constitutions of thrum plants from } \\
\text { duplex homostyle } \times \text { simplex thrum }\end{array}$}} & \multicolumn{3}{|c|}{$\begin{array}{l}\text { Ratios expected from } \\
\text { backcross }\end{array}$} \\
\hline & & & & Thrums & Homostyles & Pins \\
\hline \multirow{3}{*}{$\underset{\mathbf{H}}{\text { A distinct gene- }}$} & I & HHhh Ssss & . & 6 & 5 & I \\
\hline & $\dot{4}$ & Hhhh Ssss & . & 2 & I & I \\
\hline & $\dot{I}$ & hhhh Ssss & . & I & o & I \\
\hline \multirow{3}{*}{$\underset{\mathbf{S}^{1}}{\text { An alle- }}$} & I & $\mathrm{SS}^{1} \mathrm{~S}^{1} \mathrm{~S}$ & . & I & I & o \\
\hline & 4 & $\mathrm{SS}^{1} \mathrm{sS}$ & . & 3 & 2 & I \\
\hline & & Ssss. & . & $\mathrm{I}$ & o & I \\
\hline
\end{tabular}

It will be noted that in the first four families, four pin plants have appeared where none was expected. These were ignored for the purpose of $\chi^{2}$ calculations. However, they demonstrate the occurrence of double reduction at the locus of the $\mathbf{S}$ complex. This has an important bearing on the subject of this paper and will be considered later.

\section{DISCUSSION}

\section{(i) The structure of the $\mathbf{S}$ complex}

Since homostyly in $P$. obconica is the result of a change within the $S$ complex, the above data may be combined with those from similar, but more varied, examples, to contribute to our knowledge of the structure and behaviour of the S complex. The data of Ernst (I933 and $1936 a$ ) on the breakdown of heterostyly in $P$. viscosa and $P$. hortensis, are the most valuable. He found examples of the separation of style from anther characters, giving short and long homostyle plants which were self-fertile. Further abnormal plants showed distinction between pollen grain size and anther height. These were 
self-incompatible homostyles. Thus, three groups of characters can be genetically distinguished. These are :

I. Length of style and stigmatic papillæ, and style incompatibility reaction.

2. Anther height.

3. Pollen-grain size and incompatibility reaction.

TABLE 8

Summary of backcross ratios obtained from ig thrum plants, from the cross, long homostyle $\times$ thrum

\begin{tabular}{|c|c|c|c|c|c|c|c|}
\hline \multirow{2}{*}{$\begin{array}{l}\text { Thrum } \\
\text { parent }\end{array}$} & \multicolumn{3}{|c|}{ Backcross progeny } & \multirow{2}{*}{$x^{2}$} & \multirow{2}{*}{ D.f. } & \multirow{2}{*}{$\mathbf{P}$} & \multirow{2}{*}{$\begin{array}{l}\text { Ratio } \\
\text { tested }\end{array}$} \\
\hline & Thrum & Homostyle & Pin & & & & \\
\hline \multirow[t]{2}{*}{$\begin{array}{l}244^{2} \\
245^{4} \\
245^{5} \\
245^{8}\end{array}$} & \multirow[t]{2}{*}{$\begin{array}{l}69 \\
55 \\
64 \\
59\end{array}$} & \multirow[t]{2}{*}{$\begin{array}{l}70 \\
53 \\
59 \\
60\end{array}$} & \multirow[t]{2}{*}{$\begin{array}{l}2 \\
I \\
0 \\
I\end{array}$} & $\begin{array}{l}0.0355 \\
0.0459 \\
0.2032 \\
0.0167\end{array}$ & $\begin{array}{l}I \\
I \\
I \\
I\end{array}$ & \multirow[t]{2}{*}{$\begin{array}{l}0.8-0.9 \\
0.8-0.9 \\
0.5-0.7 \\
0.9\end{array}$} & \multirow[t]{4}{*}{$\begin{array}{c}\text { I: I : o } \\
\text { Parental } \\
\text { thrum } \\
\text { SSiS's }^{1}\end{array}$} \\
\hline & & & & 0.3013 & 4 & & \\
\hline \multirow[t]{2}{*}{ Total } & \multirow[t]{2}{*}{247} & \multirow[t]{2}{*}{242} & \multirow[t]{2}{*}{4} & $\begin{array}{l}\text { Deviation } \\
0.08^{2}\end{array}$ & $x$ & $0.8-0.7$ & \\
\hline & & & & $\begin{array}{c}\text { Heterogeneity } \\
0.218 I\end{array}$ & 3 & $0 \cdot 98-0 \cdot 95$ & \\
\hline \multirow[t]{2}{*}{$\begin{array}{l}245^{9} \\
246^{1} \\
246^{2} \\
246^{3} \\
246^{5} \\
246^{12} \\
246^{13} \\
246^{15} \\
246^{20} \\
246^{21} \\
246^{23} \\
246^{24}\end{array}$} & \multirow[t]{2}{*}{$\begin{array}{l}30 \\
70 \\
66 \\
69 \\
67 \\
61 \\
54 \\
80 \\
81 \\
67 \\
75 \\
68\end{array}$} & \multirow[t]{2}{*}{$\begin{array}{l}16 \\
39 \\
62 \\
48 \\
45 \\
41 \\
40 \\
41 \\
55 \\
46 \\
42 \\
44\end{array}$} & \multirow[t]{2}{*}{$\begin{array}{l}\text { II } \\
29 \\
42 \\
26 \\
31 \\
19 \\
25 \\
28 \\
22 \\
20 \\
24 \\
23\end{array}$} & $\begin{array}{r}0 \cdot 7894 \\
2 \cdot 6449 \\
11 \cdot 3412 \\
0 \cdot 2867 \\
2 \cdot 5874 \\
0 \cdot 0826 \\
1 \cdot 8572 \\
2 \cdot 3221 \\
0 \cdot 8671 \\
0 \cdot 2783 \\
0 \cdot 8297 \\
0 \cdot 0370\end{array}$ & $\begin{array}{l}2 \\
2 \\
2 \\
2 \\
2 \\
2 \\
2 \\
2 \\
2 \\
2 \\
2 \\
2\end{array}$ & $\begin{array}{l}0 \cdot 7 \\
0 \cdot 3 \\
<0 \cdot 01 \\
0 \cdot 9-0 \cdot 8 \\
0 \cdot 3 \\
0 \cdot 98-0 \cdot 95 \\
0 \cdot 5-0 \cdot 3 \\
0 \cdot 5-0 \cdot 3 \\
0 \cdot 7-0 \cdot 5 \\
0 \cdot 9-0 \cdot 8 \\
0 \cdot 7-0 \cdot 5 \\
0 \cdot 99-0 \cdot 98\end{array}$ & \multirow[t]{4}{*}{$\begin{array}{c}3: 2: \text { I } \\
\text { Parental } \\
\text { thrum } \\
\text { SS'ss }^{1}\end{array}$} \\
\hline & & & & $23 \cdot 9236$ & 24 & & \\
\hline \multirow[t]{2}{*}{ Total } & $7^{88}$ & \multirow[t]{2}{*}{519} & \multirow[t]{2}{*}{300} & $\begin{array}{c}\text { Deviation } \\
4 \cdot 6808\end{array}$ & 2 & $0 . x$ & \\
\hline & & & & $\begin{array}{c}\text { Heterogeneity } \\
\mathbf{1 9} \cdot 24^{2} 8\end{array}$ & 22 & $0.7-0.5$ & \\
\hline \multirow[t]{2}{*}{$\begin{array}{l}244^{1} \\
246^{11} \\
246^{18}\end{array}$} & \multirow[t]{2}{*}{$\begin{array}{l}52 \\
60 \\
64\end{array}$} & \multirow[t]{2}{*}{$\begin{array}{l}0 \\
0 \\
0\end{array}$} & \multirow[t]{2}{*}{$\begin{array}{l}64 \\
66 \\
69\end{array}$} & $\begin{array}{l}I \cdot 24 I 4 \\
0 \cdot 2857 \\
o \cdot 1880\end{array}$ & $\begin{array}{l}\text { I } \\
\text { I } \\
\text { I }\end{array}$ & \multirow[t]{2}{*}{$\begin{array}{l}0 \cdot 3-0 \cdot 2 \\
0 \cdot 7-0 \cdot 5 \\
0 \cdot 7-0 \cdot 5\end{array}$} & \multirow{4}{*}{$\begin{array}{c}\text { I : } 0: \text { I } \\
\text { Parental } \\
\text { thrum } \\
\text { Ssss }\end{array}$} \\
\hline & & & & $I \cdot 7141$ & 3 & & \\
\hline \multirow[t]{2}{*}{ Total } & 176 & $\circ$ & 199 & $\begin{array}{c}\text { Deviation } \\
1 \cdot 4107\end{array}$ & $x$ & $0.3-0.2$ & \\
\hline & & & & $\begin{array}{c}\text { Heterogeneity } \\
0.3034\end{array}$ & 2 & $0 \cdot 9-0 \cdot 8$ & \\
\hline
\end{tabular}


Of the eight forms thus possible, Ernst has found all but the selffertile thrum (see fig. 2), compared with only three forms known in $P$. obconica.

In experiments with the above plants, Ernst showed that the $\mathbf{S}$ complex is composed of at least three parts, which are tightly linked. These were termed, G, A and P to correspond with the thrum form of the three groups of characters.

SELF-COMPATIBLE-THRUM

-INCOMPATIBLE-THRUM

COMPATIBLE-SHORT HOMOSTYLE

-INCOMPATIBLE-SHORT HOMOSTYLE

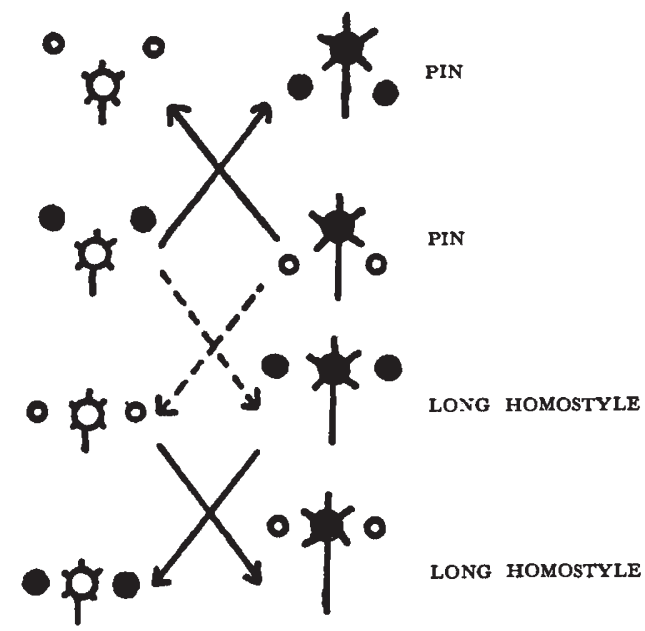

FIg. 2.-The eight possible types of flower structure and their compatibility relationships. These symbols have been modified from the usual ones to show, by difference in size of the $\delta$ parts, small or large pollen; by appendages on the stigma, short or long papilla. Shaded parts show a "pin" style reaction or a "thrum" pollen reaction ; non-shaded parts show a "thrum" style reaction or a "pin" pollen reaction.

. - . - . $\rightarrow$ all anther characters separate from all style characters

$\longrightarrow$ pollen grain size and incompatibility separate from anther height

Whether the abnormal forms arise by mutation or as a result of crossing-over will be discussed later. If they arise by mutation of parts of the $\mathbf{S}$ complex, as Ernst believes, then their order is unimportant. If, however, as seems highly probable, they result from crossing-over, then the order in which the units lie on the chromosome

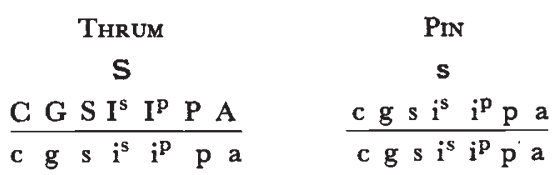

Fig. 3.-The anticipated complete structure of the $\mathrm{S}$ super gene. $\mathrm{C}=$ Thrum area of conducting tissue; $\mathrm{G}=$ Thrum style length; $\mathrm{S}=$ Thrum style papilla length ; $I^{\mathrm{s}}=$ Thrum style incompatibility; $\mathrm{I}^{\mathrm{p}}=$ Thrum pollen incompatibility ; $\mathrm{P}=$ Thrum pollen size; $\mathrm{A}=$ Thrum anther height.

is important (see table 9). From the table it seems that the order $\mathrm{P}-\mathrm{G}-\mathrm{A}$ is most unlikely since a self-compatible long homostyle, the commonest abnormality found, requires a double cross-over for its formation. Of $\mathrm{G}-\mathrm{A}-\mathrm{P}$ and $\mathrm{G}-\mathrm{P}-\mathrm{A}$, the latter is preferable 
since only one of its double-crossover types has ever been found. This order has been adopted, therefore, in this discussion.

As pointed out by Lewis (1954) incompatibility is the essence of distyly; the morphology must have arisen subsequently. Hence the $\mathbf{S}$ complex must include the original factors, for style and pollen incompatibility reaction. In addition it seems highly probable that

\section{TABLE 9}

The three possible orders of sub-genes for eight flower-types.

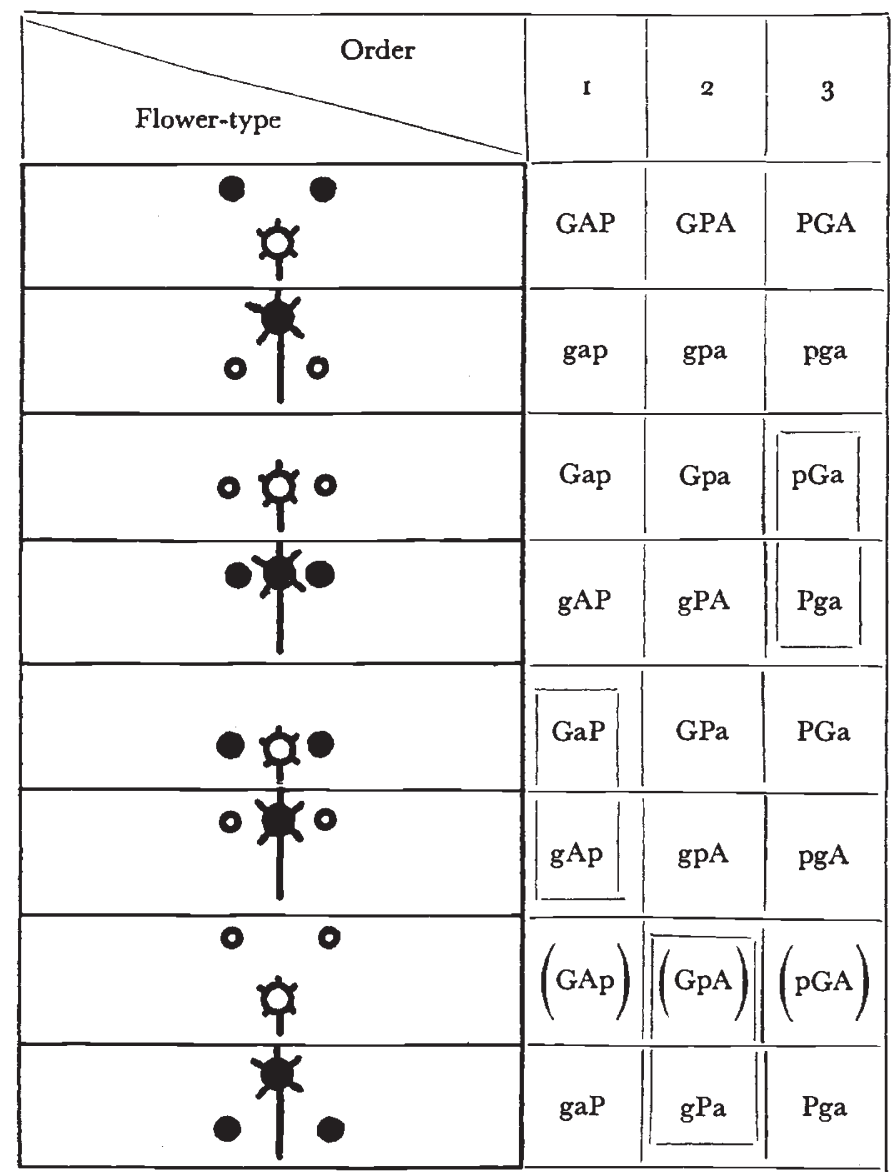

Double cross-over types are boxed in and the type so far undiscovered is in brackets.

factors for length of stigmatic papillæ and for area of conducting tissue also exist. The $\mathbf{S}$ gene may, therefore, be conceived as a complex of a number of tightly linked sub-genes (see fig. 3).

\section{(ii) The mode of breakdown in heterostyly}

Ernst (19366), supposed that abnormal plants had a mutational origin. His scheme includes the suggested origin of all forms, including pins and thrums, from gPA. This is unlikely since breakdown occurs 
in established distylic species. The scheme also involves a dominant mutation. However, mutation from GPA must be considered as a possibility. Crossing-over provides an alternative method by which new sub-gene combinations can arise. The fact that seven, out of the eight possible, have been found, and hence the corresponding recombinations, suggests that crossing-over is a likely cause. Observations in $P$. obconica and other heterostyled species support this view.

(a) Evidence from double reduction. The appearance of recessives in the progeny of backcrossed triplex plants, which has been noted in $P$. obconica, was first recognised by Blakeslee, Belling and Farnham (1923). Further tetraploid ratios, which differ from expectations on the basis of chromosome segregation, have been recorded since, and

TABLE Io

A survey of examples of double reduction

\begin{tabular}{|c|c|c|c|}
\hline Author & Tetraploid & Loci & $\begin{array}{l}\text { Frequency of } \\
\text { double reduction }\end{array}$ \\
\hline $\begin{array}{l}\text { Blakeslee, Belling and } \\
\text { Farnham (1923) }\end{array}$ & $\underset{\text { stramonium }}{\text { Datura }}$ & $\begin{array}{l}\text { Purple-white ; P-p } \\
\text { Armed-inermis ; A-a }\end{array}$ & $\begin{array}{l}4.2 \text { per cent. } \\
9 \cdot 12 \text { per cent. }\end{array}$ \\
\hline $\begin{array}{l}\text { Lawrence (I 929), } \\
\text { Lawrence and Scott- } \\
\text { Moncrieff (I } 935 \text { ) }\end{array}$ & $\begin{array}{c}\text { Dahlia } \\
\text { variabilis }\end{array}$ & Yellow-non-yellow; Y-y & 6.12 per cent. \\
\hline $\begin{array}{l}\text { de Winton and Haldane } \\
\text { (I935) }\end{array}$ & $\begin{array}{l}\text { Primula } \\
\text { sinensis }\end{array}$ & Green-red ; G-g & $4 \cdot 8-7 \cdot 8$ per cent. \\
\hline Mather (1936) . & $\begin{array}{l}\text { Lycopersicon } \\
\text { esculentum }\end{array}$ & Red-non-red ; R-r & $\frac{1}{2}(o \cdot 2 I \pm \cdot 079)$ \\
\hline Fisher (1949) . & $\begin{array}{l}\text { Lythrum } \\
\text { salicaria }\end{array}$ & $\begin{array}{l}\text { Purple-rosy ; R-r } \\
\text { Short-non-short ; S-s }\end{array}$ & $\begin{array}{l}6.5 \text { per cent. } \\
2.5 \text { per cent. }\end{array}$ \\
\hline Fyfe (1953) & $\begin{array}{l}\text { Lythrum } \\
\text { salicaria }\end{array}$ & Mid-non-mid ; M-m & $9 \cdot 878 \pm \cdot 936$ per cent. \\
\hline
\end{tabular}

The above values were calculated from triplex backcross data, except for those of Fisher and Mather. They used data from backcrossed simplex plants.

examples of such loci are given in table Io. Darlington (I929) showed that this was due to "double reduction, where both chromatids of one chromosome pass into the same nucleus at the second telophase". And, in 193 I, he showed that this would result in ratios intermediate between the expectations for random chromatid and diploid segregations. The frequency of double reduction, $\alpha$, is the "proportion of gametes containing homologous genes from identical meiotic chromatids" (Fisher and Mather, 1943). It is therefore a measure of the distance of the locus from the centromere.

The results in table 8 show that double reduction occurs at the locus of the $\mathbf{S}$ complex in tetraploid $P$. obconica. Four recessives appeared among 493 plants from backcrossed triplex thrums $\left(\mathbf{S S}^{1} \mathbf{S}^{1} \mathbf{s}\right)$. 
This is a frequency of $0.8 \mathrm{I}$ per cent. recessives, giving an estimate of $\alpha=3.2$ per cent. for ovules. (Double reduction is not evident in normal populations of simplex thrums and pins since it would only be recognised by identifying occasional duplex thrums, thus involving a further generation).

\section{TABLE I I}

Breakdown of heterostyly in relation to polyploidy

\begin{tabular}{|c|c|c|c|c|c|}
\hline \multicolumn{6}{|c|}{ Species with breakdown of heterostyly } \\
\hline \multirow{2}{*}{ Polyploid species } & \multicolumn{2}{|c|}{ No. of abnormal types } & \multirow{2}{*}{ Diploid species } & \multicolumn{2}{|c|}{ No. of abnormal types } \\
\hline & (a) sporadic & (b) populations & & (a) sporadic & (b) populations \\
\hline 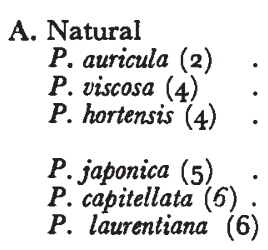 & $\begin{array}{r}6 \\
6 \mathrm{I} \\
\mathrm{I} \\
\cdots \\
\cdots \\
\cdots\end{array}$ & $\begin{array}{r}\cdots \\
\cdots \\
\cdots \\
>1 \\
>1\end{array}$ & $\begin{array}{l}\text { P. veris (2) } \\
P . \text { yunnanensis (6) } \\
\text { F. esculentum (9) } \\
\text { L. salicaria (Io) } \\
P . \text { malacoides (I I) } \\
P . \text { vulgaris (I I) }\end{array}$ & $\begin{array}{l}\text { I } \\
\text { I } \\
\text { I } \\
\text { I } \\
\text { I } \\
\text { I }\end{array}$ & $\begin{array}{l}\cdots \\
\cdots \\
\cdots \\
\cdots \\
\cdots\end{array}$ \\
\hline $\begin{array}{l}\text { B. Artificial } \\
\text { F. esculentum (7) } \\
\text { L. salicaria }(7) \\
P . \text { malacoides (8) } \\
\text { P. obconica (1 2) }\end{array}$ & $\begin{array}{l}3 \\
3 \\
1 \\
2\end{array}$ & $\begin{array}{l}\cdots \\
\cdots \\
\cdots\end{array}$ & $\begin{array}{l}\text { P. vulgaris }(\mathrm{I}) \\
P . \text { chungensis }(5)\end{array}$ & $\begin{array}{l}\cdots \\
\cdots\end{array}$ & $\begin{array}{r}2 \\
>1\end{array}$ \\
\hline $\begin{array}{c}\text { No. of species } \\
\text { with no breakdown }\end{array}$ & & & $\begin{array}{c}\text { No. of species } \\
\text { with } \\
\text { no breakdown }\end{array}$ & & \\
\hline 13 & & & $43(3,5,6,12)$ & & \\
\hline Total 23 & 78 & $>3$ & Total ${ }_{5 I}$ & 6 & $>3$ \\
\hline Frequency of abnorm & types per & ecies 3.52 & & & 0.18 \\
\hline
\end{tabular}

$>$ has been used in the above table where more than one population, but an unknown number, contain abnormal types. The minimum figure has been used in calculations of frequencies. Sources of data are :-(1) Crosby, I949b ; (2) Darwin, I869; (3) Ernst, I928; (4) 1936b; (5) 1938; (6) I953; (7) Esser, I953 ; (8) Kobel, I927 ; (9) Schoch-Bodmer, I934; (Io) Stout, I925 ; (I I) v. Ubisch, I923 ; (12) this paper.

Therefore, crossing-over in the region of the $\mathbf{S}$ complex does occur in tetraploid $P$. obconica. In Lythrum, too, where there is a similar breakdown of heterostyly, double reduction, affecting the $\mathbf{S}$ and $\mathbf{M}$ loci is also found (Fisher, 1949 and Fyfe, 1953).

In $P$. sinensis, however, where there is no such breakdown of the S complex, de Winton and Haldane (1935) found no double reduction at the $\mathbf{S}$ locus in 434 plants, indicating that, should it occur, $\alpha$ must 
be less than $0.9^{2}$ per cent. This suggests that centromere interference prevents crossing-over within the $\mathbf{S}$ locus in this species. It is then unnecessary to assume, as Mather (I950) has done, that the S locus lies in an inversion.

(b) Evidence from polyploidy. It seems certain that the homostyle in tetraploid $P$. obconica did not arise by the doubling-up of a diploid homostyle. No case of homostyly has been reported in the diploid. In fact, Ernst (1928), examined 8000 plants for homostyles without success, and similarly, I have found none among 5000 plants.

A single tetraploid pin or thrum could not be fertilised, but it is possible that the tetraploid race of $P$. obconica might have arisen from a single doubled-up self-fertile homostyle. In such a case the tetraploids would consist of homostyles and pins only, but thrums are also present. Moreover, the first long homostyle used in this work was a single plant among ten pins and thrums obtained from a nursery. Examination of further tetraploids of the same variety from the same

TABLE 12

Classification of abnormal types resulting from breakdown of distyly. The literature used is cited in table 12

\begin{tabular}{|c|c|c|c|c|c|c|}
\hline Abnormal types & $\mathrm{gPA} *$ & $\mathrm{Gpa}$ & $\mathrm{GPa}$ & $\mathrm{gpA}$ & $\mathrm{gPa}$ & $\mathrm{GpA}$ \\
\hline Number found & 64 & 3 & 6 & 4 & 5 & 0 \\
\hline
\end{tabular}

* The gPA populations are not included.

source showed no other cases of homostyly, so that this could not have been one of a segregating genotype.

Another case of homostyly in tetraploid $P$. obconica was noticed by a nurseryman in the variety Eureka in 1944. A r940 seed catalogue description shows that it was already a tetraploid variety. All this evidence points to the fact that homostyly arose after polyploidy in P. obconica.

Further striking examples of the occurrence of breakdown in heterostyly in artificially polyploid species, are provided by the work of Esser (1953). He remarks upon the occurrence of three homostyles in progeny from his new Lythrum tetraploids and three more in progeny of newly formed tetraploid Fagopyrum. He states that this may either be the result of spontaneous mutation after colchicine treatment or of a new combination of the sub-genes which may occur as the result of chromosome doubling.

In fact, there is a tendency for breakdown in heterostyly to appear in both natural and artificial polyploid forms. A survey of known examples is given in table II. The species, $P$. hortensis and $P$. viscosa, in which Ernst found considerable breakdown are naturally polyploid.

It has been shown (Darlington, 1940), that in trivalents, and 
therefore presumably in quadrivalents, there is both a change in distribution of chiasmata and an increase in their frequency. Lewis (1954) suggested that the former would increase the chance of crossing over within the $\mathbf{S}$ complex. In fact, either or both of these effects could be responsible. There is thus an explanation for the preponderance of breakdown in polyploid heterostyles, assuming a

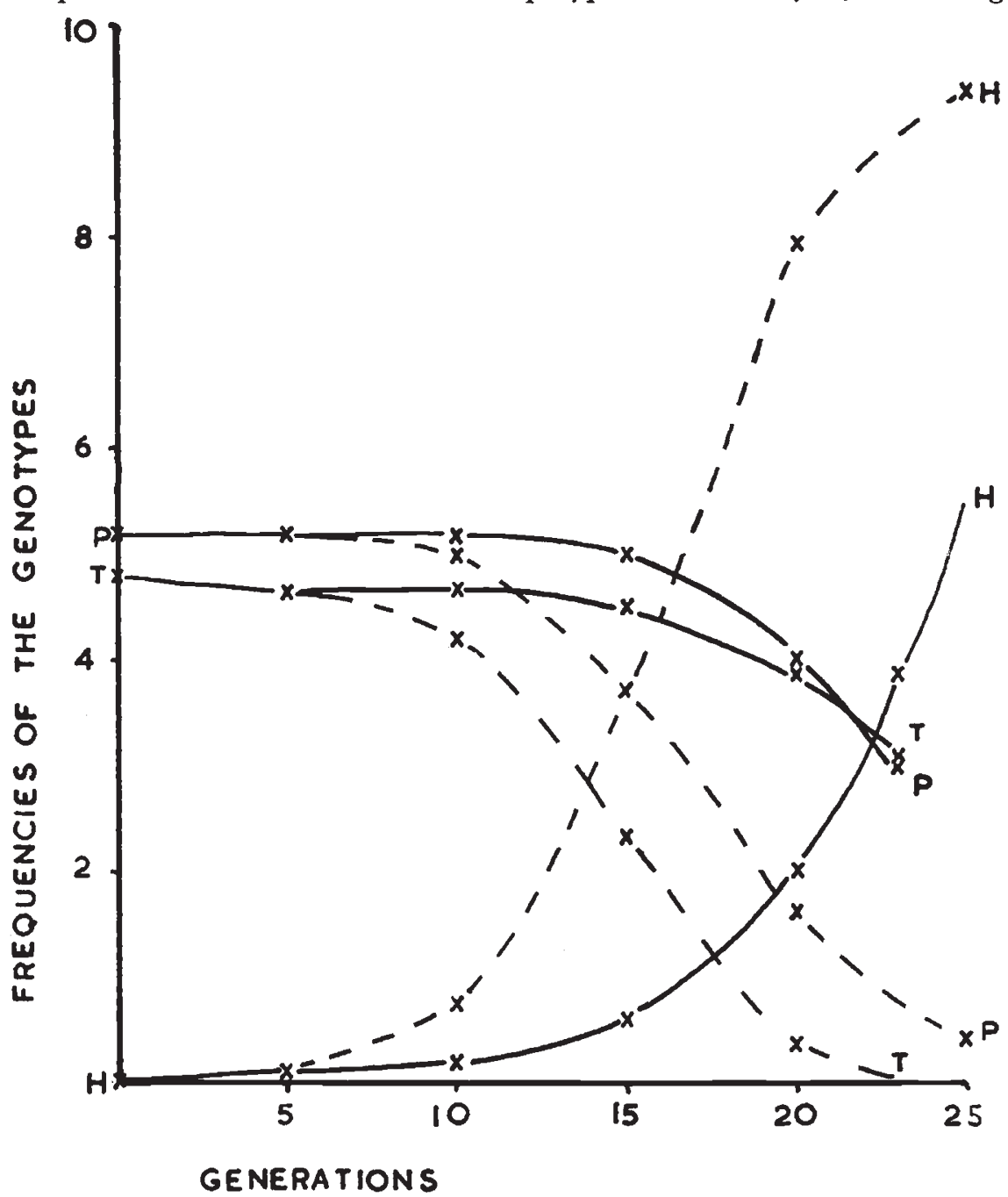

FIG. 4.-Graph comparing the rate of increase of short homostyles with that of long homostyles in similar populations. Generations from arbitrary starting point :-

- - Crosby (1949) for a population with I long homostyle : 499 pins and thrums. for a population with i short homostyle : 499 pins and thrums.

$$
\mathrm{T}=\text { total thrums } \quad \mathrm{P}=\text { Pins } \quad \mathrm{H}=\text { total homostyles }
$$

cross-over origin. It is difficult to see how polyploidy could affect mutational breakdown.

(c) The occurrence of unequal proportions of corresponding cross-over types. It will be noted that in table 12 there is a high proportion of 
the type, gPA, among examples of breakdown in heterostyly. The most striking of these are Crosby's population of $P$. vulgaris, where there are up to 90 per cent. of long homostyles, and Ernst's populations of $P$. viscosa. If these abnormal types are formed by crossing-over it would be expected that gPA and the corresponding cross-over type Gpa, the self-fertile short homostyle, would occur in approximately equal numbers. However, a difference in proportions of the two forms could arise in two ways : (i) if they were of mutational origin, and (ii) if one form had a selective advantage over the other, caused by a difference either in viability or in breeding relationships. The rarity of $\mathrm{Gpa}$ in comparison with gPA in thirteen species suggests that it is not simply a question of the unfavourable viability of Gpa.

Among the external forces which will most affect the success of a new genotype are its breeding relationships with members of the population in which it arises. In order to explain the high frequency of gPA, Crosby (1940), devised a theoretical scheme for calculating the approximate trend of a population of 500 plants containing one heterozygous long homostyle, assuming that the relative viability of the homozygotes was I (i.e. equal to the other types). He found, however, that natural populations of $P$. vulgaris corresponded to a relative viability of 0.65 for the homozygous homostyles.

I have worked out a similar scheme for a population in which one heterozygous short homostyle appears. The same assumptions were adopted, except that the cross, short homostyle $\times$ pin, was considered to be unimportant because of the frequent occurrence of selfing in the homostyle. Since thrums are, in this case, involved in crosses with the homostyle, they are of two genotypes, Ss and SS ${ }^{1}$. Both of these must be considered in each type of cross in which thrums are concerned. This case is thus rather more complex than the $P$. vulgaris one.

The results are summarised in fig. 4. It can be seen that the rate of increase of the short homostyles is much slowes than that of long homostyles. They will therefore always be at a disadvantage. Furthermore, if the relative viability of homozygous short homostyles was less than unity, the increase would be even slower, and they might be completely eliminated before ever becoming established.

\section{CONCLUSIONS}

The morphological characters associated with distyly in $P$. obconica are similar to those in other Primula species. In fact, there is evidence that a new one, affecting the fertility of the two forms in $P$. obconica, also occurs in other species. This provides further evidence of the widespread uniformity in distyly.

It is clear that tetraploidy has no effect on the expression of the $\mathbf{S}$ gene in $P$. obconica. The incompatibility system is maintained in the tetraploid and $\mathbf{S}$ shows complete dominance in both style and 
pollen. Therefore, here, as opposed to gametophytic systems tetraploidy does not result in loss of incompatibility. This is in agreement with the findings in other sporophytic systems (Lewis, 1954). In these there is interaction of alleles in the normal diploid condition, so that polyploidy brings no new situation and no breakdown of the incompatibility system.

The effect of tetraploidy in inducing breakdown of heterostyly, which may result in self-compatibility, is quite distinct from the loss of incompatibility in tetraploids of species with gametophytic control. It involves changes in $\mathbf{S}$ gene structure. The fact that the more frequent occurrence of breakdown can be explained by known cytological effects of polyploidy, i.e. alterations in number and position of chiasmata, suggests that it is produced by crossing-over. There seems to be no reason to assume an increased mutation rate in polyploids. That crossing-over can occur in this region is shown by double reduction at the $\mathbf{S}$ locus in P. obconica and at the $\mathbf{S}$ and $\mathbf{M}$ loci in Lythrum.

In $P$. obconica, no genes linked with $\mathbf{S}$ have so far been found. It is therefore impossible to prove crossing-over within the $\mathbf{S}$ gene. The evidence described supports the view that it does occur. In addition, recent work has shown that a number of multiple-allelic systems are in fact pseudo-alleles or complex genes. From such evidence, the concept that the gene may occupy a chromosome segment larger than the unit of crossing-over is derived. This view makes it even more probable that breakdown of heterostyly is by crossing-over within the $\mathbf{S}$ super gene. If this is so, the $\mathbf{S}$ complex in Primula belongs to the class showing no position effect, since Ernst could make up, for example, thrums of genotype, $\frac{\mathrm{GPA}}{\mathrm{gpA}}$, (a trans heterozygote instead of the normal cis arrangement). Other examples of this type of complex gene include loci in Aspergillus, Gossypium, Maize, Oenothera, Drosophila, Mouse and Man (Pontecorvo, 1952).

The more frequent occurrence of breakdown of the $\mathbf{S}$ complex in polyploids suggests a possible breeding technique. If tetraploidy facilitates the breakdown of close linkages by the altered position and frequency of chiasmata in quadrivalents, it could be used as a method of surmounting undesirable tight linkages in breeding work. The possibilities of this method are being investigated with new colchicineinduced tetraploids of $P$. obconica.

\section{SUMMARY}

I. Primula obconica has a distylic breeding system controlled by a single " gene " pair, S-s. In the tetraploid, S is completely dominant.

2. The two mating types are distinguished morphologically by a group of characters. A difference in fertility of the two compatible crosses, pin $\times$ thrum and thrum $\times$ pin, is shown to be a consequence 
of an additional character-a restriction of the area of conducting tissue of pin styles..

3. Breakdown of dimorphic incompatibility has occurred in tetraploid varieties, giving self-fertile homostyles.

4. Homostyly is controlled by the S complex. The "allele" is recessive to thrum but dominant over pin (ss).

5. This " allele" is probably a new combination of sub-genes of the $S$ complex. It could be formed either by intragenic mutation or crossing-over.

6. That crossing-over does occur in this region is shown by double reduction at the locus of the $\mathbf{S}$ complex.

7. There is evidence that polyploidy induces breakdown of the $\mathrm{S}$ complex. This can be explained by the change in position and increase of crossing-over in quadrivalents.

8. Corresponding cross-over types are not necessarily expected in equal numbers in the wild, because some have disadvantageous breeding relationships which would eliminate them initially.

9. It is at present impossible to confirm the occurrence of crossingover within the $\mathbf{S}$ complex. Evidence favours this as a highly probable cause of breakdown in heterostyly.

Acknowledgments. I wish to express my thanks to $\mathrm{Dr} \mathrm{D}$. Lewis, F.R.s. for suggesting this problem and for his continual advice.

\section{REFERENCES}

BLAKESLEE, A. F., BELLING, J., AND FARNhAM, M. E. 1923. Inheritance in tetraploid Daturas. Bot. Gaz., 76, 329-373.

GROSBY, J. L. 1949a. Evolution from heterostyly to homostyly in natural populations of Primula vulgaris. Proc. 8th Int. Congr. Genetics 1948, Hereditas (Suppl.), 554-555 (Abst.)

GROSBY, J. L. 1949b. Selection of an unfavourable gene complex. Evolution, 3, 212-230.

DARLINGTON, c. D. 1929. Chromosome behaviour and structural hybridity in the Tradescantiae. F. Genet., 21, 207-286.

DaRlington, c. D. 1931. Meiosis in diploid and tetraploid Primula sinensis. $\mathcal{F}$. Genet., 24, 65-96.

DARLington, C. D. 1940. The causal sequence of meiosis. II. Contact points and crossing over potential in a triploid Fritillaria. 7. Genet., $4 I, 35-48$.

DARLington, C. D., AND LA COUR, L. F. 1947. The Handling of Chromosomes. London. DARWIN, c. 1862. On the two forms, or dimorphic condition, in the species of Primula, and on their remarkable sexual relations. F. Linn. Soc. (Bot.), 6, 77-96.

DARWIN, c. 1869. On the character and hybrid-like nature of the offspring from the illegitimate unions of dimorphic and trimorphic plants. F. Linn. Soc. (Bot.), ro, 393-437.

DARWIN, c. 1877. The Different Forms of Flowers on Plants of the Same Species. London. DE Winton, D., AND haldane, J. B. S. 1935. The genetics of Primula sinensis. III. Linkage in the diploid. $\mathcal{F}$. Genet., $3^{I}, 67-100$.

ERNST, A. 1928. Zur Vererbung der morphologischen Heterostylie-merkmale. Ber. dtsch.-bot. Ges., 46, 573-588.

ERNST, A. 1933. Weitere Untersuchungen zur Phänanalyse, zum Fertilitätsproblem und zur Genetik heterostyler Primeln. I. Primula viscosa. Arch. Klaus-Stift. Vererb. Forsch., 8, 1-215. 
ERNST, A. 1936a. Weitere Untersuchungen zur Phänanalyse, zum Fertilitätsproblem und zur Genetik heterostyler Primeln. 2. Primula hortensis. Arch. Klaus-Stift. Vererb. Forsch., II, 1-280.

ERNST, A. 1936b. Heterostylie-Forschung Versuche zur genetischen Analyse eine. Organisations-und "Anpassungs" merkmales. Z. indukt. Abstamm.-us Vererb. Lehre, 7I, I 56-230.

ERNST, A. 1938. Stammegeschichliche Untersuchungen zum Heterostylieproblem. Ber. schweiz.-bot. Ges., 48, 85-238.

ERNST, A. 1953. "Basic numbers" und Polyploidie und ihre Bedeutung für das Heterostylieproblem. Arch. Klaus-Stift. Vererb. Forsch., 27, 1-159.

ESSER, K. I 953 . Genomverdopplung und Pollenschlauchwachstum bei Heterostylen. Z. indukt. Abstamm.-u. Vererb. Lehre, 85, 28-50.

FISHER, R. A. 1949. The linkage problem in a tetrasomic wild plant, Lythrum salicaria. Proc. 8th Int. Cong. Genetics, 1948, Hereditas (Suppl.), 223-233.

FISHER, R. A., AND MATHER, K. 1943. The inheritance of style length in Lythrum salicaria. Ann. Eugen., I2, I-23.

FYFFE, v. c. 1953. Double reduction at the mid locus in Lythrum salicaria. Heredity, $7,285-292$.

KOBEI, F. 1927. Uber eine tetraploide (Gigas)-Form von Primula malacoides. Ber. schweiz.-bot. Ges., 36, XXV-XXVI.

LAWRENCE, W. J. C. 1929. The genetics and cytology of Dahlia species. F. Genet., 2I, I 25-I 59 .

LAWRENCE, W. J. C., AND SCOTT-MONCRIEFF, R. I935. The genetics and chemistry of flower colour in Dahlia : a new theory of specific pigmentation. 7. Genet., 30, $155-226$.

LEWIS, D. 1954. Comparative incompatibility in Angiosperms and Fungi. Advanc. Genet., 6, 235-285.

MATHER, K. 1936. Segregation and linkage in autotetraploids. F. Genet., 32, 287-314.

Mather, K. 1950. The genetical architecture of heterostyly in Primula sinensis. Evolution, 4, 340-352.

MODLibowsKa, I. 1942. Bimodality of crowded pollen tubes in Primula obconica. 7. Hered., 33, 187-19o.

PONTECoRvo, G. 1952. Genetical analysis of cell organisation. Symp. Soc. exp. Biol., 6, $218-229$.

SCHOCH-BODMER, H. 1934. Griffelbeschaffenheit und Pollenschlauchwachstum bei Fagopyrum esculentum. Planta, 22, 149.

Stout, A. B. 1925. Studies in Lythrum salicaria. 2. A new form of flower in this species. Bull. Torrey. bot. Cl., 52, 81.

UBisch, G. v. 1923. Versuche über Vererbung und Fertilität bei Heterostylie und Blütenfüllung. Z. Bot., 15, 193-232. 